\title{
AROMA PROFILE AND PHENOLIC CONTENT OF MERLOT RED WINES PRODUCED IN HIGH-ALTITUDE REGIONS IN BRAZIL
}

\author{
Stefany Grutzmann Arcari ${ }^{\mathrm{a}, \mathrm{b}, *,(1)}$, Vinícius Caliari ${ }^{\mathrm{c}, \mathrm{d}}$, Edson Luiz de Souza ${ }^{\mathrm{d}}$ and Helena Teixeira Godoy ${ }^{\mathrm{a}, \#}$ \\ aDepartamento de Ciência de Alimentos, Faculdade de Engenharia de Alimentos, Universidade Estadual de Campinas, 13083-862 \\ Campinas - SP, Brasil \\ 'Instituto Federal de Santa Catarina, Campus São Miguel do Oeste, 89900-000 São Miguel do Oeste - SC, Brasil \\ 'EPAGRI - Estação Experimental de Videira, 89560-000, Videira - SC, Brasil \\ ${ }^{\mathrm{d} U n i v e r s i d a d e ~ d o ~ O e s t e ~ d e ~ S a n t a ~ C a t a r i n a, ~ C a m p u s ~ V i d e i r a, ~ 89560-000 ~ V i d e i r a ~-~ S C, ~ B r a s i l ~}$
}

Recebido em 22/07/2020; aceito em 09/11/2020; publicado na web em 09/12/2020

\begin{abstract}
In Brazil, wine-growing regions of high altitude have been evaluated for the cultivation of grapes destined for the production of quality wines. In this study the phenolic content, the volatile compounds profile and the in vitro antioxidant activity of samples produced in Água Doce, Campos Novos and Tangará were determined using spectrophotometric and chromatographic techniques. A total of 95 volatile compounds were identified in the samples analyzed, of which borneol is reported in Brazilian Merlot wines for the first time. The quantitative results showed that the most important volatile compounds for wine aroma were esters, fatty acids, 1-hexanol and 2-phenylethanol alcohols, and $\mathrm{C}_{13}$-norisoprenoids $\beta$-damascenone and $\alpha$-ionone. The phenolic content observed was comparable to the results obtained for Merlot red wines from other regions in Brazil and in other countries. Also, the wine samples were effective in capturing the free radicals DPPH and ABTS.
\end{abstract}

Keywords: Merlot wines; volatile compounds; phenolic compounds; antioxidant activity.

\section{INTRODUCTION}

In recent years, there has been an increase in the number of wine-growing regions around the world, with the spread of grapevine cultivation to latitudes of the globe with productive potential still little explored. ${ }^{1}$ In Brazil, new wine regions have emerged that are favorable for the cultivation of varieties of Vitis vinifera L., although approximately $90 \%$ of the Brazilian wines come from Serra Gaúcha, in southern Brazil. In this context, viticulture in the highaltitude regions of Brazil has been highlighted, with some studies demonstrating the potential of these regions for the production of quality wines. $^{2-5}$

In Santa Catarina State, also in southern Brazil, three different regions with altitudes of $900 \mathrm{~m}$ above sea level or higher are being evaluated regarding the potential for the elaboration of wines. The Serra de Marari, located in the region of Tangará, at an altitude of up to $1211 \mathrm{~m}$ above sea level, has a temperate climate, with an average annual temperature of $16{ }^{\circ} \mathrm{C}$, mountainous terrain, and basaltic formations. Campos Novos has an average altitude of $934 \mathrm{~m}$ above sea level, humid and temperate climate, with average temperatures ranging between 15 and $19^{\circ} \mathrm{C}$ and deep and well-drained soils. Água Doce, in the Planalto de Palmas, has an average altitude of $1300 \mathrm{~m}$, a humid and mesothermal climate, cool summers and severe winters, average annual temperature of $16{ }^{\circ} \mathrm{C}$ and a terrain with plains and valleys. $^{6}$

For young monovarietal wines, the chemical composition of the wine is strongly dependent on the terroir, that is, the geographical characteristics of the region in which the grapes were produced and the wine was made. This set of factors includes all of the regional parameters that affect the chemical composition of wine, such as the soil, climate, topography and cultural factors involved in the wine production process.?

*e-mail: arcari.ste@gmail.com

\#alternative e-mail: helena@fea.unicamp.br
The aroma and phenolic content of wine are determinants of consumer preference and contribute to the definition of the chemical composition of wines from new wine-growing regions. The aroma profile of a wine is determined by the combination of chemical compounds such as alcohols, esters, aldehydes, acids, monoterpenes and other minor components, which influence the sensory characteristics. The composition of the volatile fraction of the wine derives from the grape production process, including environmental factors, besides being influenced by the technologies applied for the preparation of the must and by the fermentation and aging process. ${ }^{8}$ The phenolic compounds contribute mainly to the color, flavor, astringency and bitterness of the wine. They are classified into flavonoids, including anthocyanins, flavan-3-ol and flavonols, and non-flavonoids, for example, phenolic acids and stilbenes. Some studies indicate that the phenolic composition may be affected by the grape variety, grape harvest, winemaking techniques and wine aging. ${ }^{9,10}$

In this study, Merlot wines produced in three high-altitude regions in Santa Catarina State, southern Brazil, from three different harvests (2012, 2013 and 2014) were evaluated. The volatile profile, phenolic composition and in vitro antioxidant activity were determined to provide, for the first time, information on the chemical profile of Merlot wines produced in these new Brazilian wine regions.

\section{EXPERIMENTAL}

\section{Reagents and solutions}

The analytical standards of the volatile and phenolic compounds studied were obtained from Sigma-Aldrich (St. Louis, MO, USA), with a purity equal to or greater than $98 \%$ : ethyl acetate (141-78-6), ethyl butanoate (105-54-4), ethyl pentanoate (539-82-2), ethyl hexanoate (123-66-0), ethyl heptanoate (106-30-9), ethyl octanoate (106-32-1), ethyl nonanoate (123-29-5), ethyl decanoate (110-383 ), ethyl undecanoate (627-90-7), ethyl dodecanoate (106-33-2), 
diethyl succinate (123,25-1), ethyl lactate (97-64-3), ethyl cinnamate (103-36-6), ethyl anthranilate (87-25-2), ethyl isobutanoate (97-62-1), ethyl 3-hydroxybutanoate (5405-41-4), ethyl isovalerate (108-64-5), ethyl 2-methylbutanoate (7452-79-1), phenylethyl acetate (103-45-70, hexyl acetate (142-92-7), S-furfuryl thioacetate (13678-68-7), furfuryl acetate (623-17-6), isobutyl acetate (110-19-0), isoamyl acetate (123-92-2), 3-methyl-1-butanol (123-51-3), methanol (67-56-1), 1-butanol (71-36-3), 2-butanol (78-92-2), 1-propanol (71-23-8), 2-phenyletanol (60-12-8), 1-hexanol (111-27-3), furfuryl alcohol (98-00-0), propanoic acid (79-09-4), butanoic acid (107-92-6), valeric acid (109-52-4), hexanoic acid (142-62-1), heptanoic acid (111-14-8), octanoic acid (124-07-2), pelargonic acid (112-05-0), decanoic acid (334-48-5), undecanoic acid (112-37-8), 10-undecenoic acid (112-38-9), isobutyric acid (79-31-2), isovaleric acid (503-74-2), $\alpha$-pinene (7785-70-8), $\beta$-pinene (19902-08-0), geraniol (106-24-1), $\alpha$-terpineol (98-55-5), limonene (5989-27-5), citronelal (2385-77-5), cedrene (469-61-4), $\gamma$-nonalactone (104-61-0), $\beta$-damascenone (23696-85-7), $\alpha$-ionone (127-41-3), $\beta$-ionone (14901-07-6), nonanoic acid (112-05-0), $\beta$-terpineol (138-87-4), ethyl propanoate (105-37-3), caffeic acid (331-39-5), $p$-coumaric acid (501-98-4), ferulic acid (1135-24-6), vanillic acid (121-34-6), syringic acid (530-57-4), protocatechuic acid (99-50-3), gallic acid (149-91-7), quercetin (6151-25-3), kaempferol (520-18-3), (+)-catechin (154-23-4), (-)-epicatechin (490-46-0), tyrosol (501-94-0), trans-resveratrol (501-36-0). The internal standard used was 4-methyl-2-pentanol, and a mixture of $\mathrm{C}_{8}-\mathrm{C}_{20}$ hydrocarbons was obtained from Sigma-Aldrich. Ethanol, methanol, acetonitrile, acetic acid and sodium chloride were purchased from Synth (Diadema, SP, Brazil). Ultrapure water was obtained from a Milli-Q purification system (Millipore, Bedford, MS, USA). For each compound studied, a stock solution at $100 \mathrm{mg} \mathrm{L}^{-1}$ was prepared in $50 \%$ ethanol and stored at $4{ }^{\circ} \mathrm{C}$. Standard solutions were prepared in synthetic wine $\left(5 \mathrm{~g} \mathrm{~L}^{-1}\right.$ tartaric acid, $11 \%$ ethanol, $\left.\mathrm{pH} 3.5\right)$.

\section{Samples}

Nine samples of Merlot red wines, prepared by microvinification, were included in this study. Wines from 2012, 2013 and 2014 harvests in three different growing regions in Santa Catarina State, Brazil, were analyzed. The grapes were collected when reached technological maturity (total soluble solids $\approx 22^{\circ}$ Brix, titratable acidity $\approx 0.60 \mathrm{mg}$ tartaric acid. $100 \mathrm{~g}^{-1} ; \mathrm{pH} \approx 3.4$; maturity index $\approx 40$ ), from vineyards located in experimental areas managed by Epagri: Campos Novos Experimental Station, Campos Novos (altitude of 965 meters, latitude $27^{\circ} 19^{\prime} 83^{\prime \prime} \mathrm{S}$ and longitude 50॰49'18'W); Winery Pisani, located in Marari, Tangará (altitude of 1059 meters, latitude $27^{\circ} 12$ '24'S and longitude $\left.51^{\circ} 06^{\prime} 96^{\prime \prime} \mathrm{W}\right)$; and Winery Villaggio Grando, Água Doce (altitude of 1300 meters, latitude 26 $43^{\circ}$ '53"S and longitude $\left.51^{\circ} 30^{\prime} 26^{\prime \prime} \mathrm{W}\right)$

Merlot grapes were harvested when mature and transported to the Epagri Experimental Station of Videira, Santa Catarina State. The grapes were separated from the bunches and kept in a stainless steel tank $(20 \mathrm{~L})$. The maceration period was ten days, with two daily reruns. The must was separated from the solid parts and transferred to a stainless steel tank. Before starting the alcoholic fermentation, sulfite $\left(10 \mathrm{mg} \mathrm{L}^{-1}\right.$ free $\mathrm{SO}_{2}$ ) and strains of Saccharomyces cerevisiae PB2019 (Fermol Blanc, AEB Spa, Brescia, Italy) were added. The decarboxylation of malic acid by lactic acid bacteria occurred spontaneously, without the addition of inoculum. After the alcoholic fermentation, the wines were stabilized for 20 days at a temperature of $4{ }^{\circ} \mathrm{C} \pm 1{ }^{\circ} \mathrm{C}$, added to the free $\mathrm{SO}_{2}\left(40 \mathrm{mg} \mathrm{L}^{-1}\right)$ and then bottled. Microvinifications were performed in duplicate. All samples were stored in a cellar at $18{ }^{\circ} \mathrm{C}$ and $70 \%$ relative humidity until the analysis was carried out.

\section{Determination of volatile compounds}

\section{Headspace Solid Phase Microextraction (HS-SPME)}

Sample prepare was carried out according to the methodology of Arcari et al.: ${ }^{11}$ a $1 \mathrm{~cm}$ divinylbenzene/carboxen/polydimethylsiloxane (DVB/CAR/PDMS) 50/30 $\mu \mathrm{m}$ fiber obtained from Supelco (Bellefonte, PA, USA) was used in the experiments after previous conditioning according to the manufacturer's recommendations. In each test, $1.5 \mathrm{~g}$ of $\mathrm{NaCl}$ and $5 \mathrm{~mL}$ of sample were placed in a $20 \mathrm{~mL}$ vial. The HS-SPME procedure was performed using a Triplus-RSH autosampler (Thermo Fisher Scientific, USA) and ChromQuest software (Thermo Fisher Scientific, USA). Samples were incubated for $5 \mathrm{~min}$ at $56^{\circ} \mathrm{C}$ under continuous agitation $(250 \mathrm{rpm})$, and the fiber was then exposed to the headspace for $55 \mathrm{~min}$. The desorption in the gas chromatograph injector was performed for $2 \mathrm{~min}$ at a temperature of $265^{\circ} \mathrm{C}$ in the splitless mode.

\section{Identification and quantification of volatile compounds}

The volatile compounds were qualitatively determined using a gas chromatograph Varian CP-3800 (USA) GC-IT/MS equipped with an ion trap analyzer (Varian Saturn 4000, USA) and Saturn GC-IT/MS Workstation software, version 5.4. The ion trap detector was operated at temperatures of $200{ }^{\circ} \mathrm{C}$ in the transfer line, $50{ }^{\circ} \mathrm{C}$ in the manifold and $180{ }^{\circ} \mathrm{C}$ in the trap. All mass spectra were obtained by electron impact $(70 \mathrm{eV})$, in the scan mode $(25-400 \mathrm{~m} / \mathrm{z})$. The emission current was $50 \mu \mathrm{A}$, with a maximum ionization of $25000 \mu \mathrm{s}$. The chromatographic separation was performed using a ZB-WAXplus column (60 m x $0.25 \mathrm{~mm}$ x $0.25 \mu \mathrm{m})$ (Zebron, USA) and helium gas as the carrier gas at a flow rate of $1.0 \mathrm{~mL} \mathrm{~min}^{-1}$. The initial oven temperature was $40{ }^{\circ} \mathrm{C}$ for 5 min increasing by $2{ }^{\circ} \mathrm{C}$ per min until reaching $220^{\circ} \mathrm{C}$. The detector temperature was $250{ }^{\circ} \mathrm{C}$.

The positive identification of the compounds was performed by comparison of the retention time obtained for the sample with that observed for the standards of the volatile compounds injected under the same conditions and also based on a comparison of the mass spectra with those given in the spectral database of the National Institute of Standards and Technology (NIST) MS 05, considering above $70 \%$ similarity. Also, in the MS data processing the automated mass spectral deconvolution and identification system (AMDIS), program version 2.71, was used. The retention index (LTPRI - linear temperature programmed retention index) was also calculated using a commercial hydrocarbon mixture $\left(\mathrm{C}_{8}-\mathrm{C}_{20}\right)$. The tentative identification of other volatile compounds present in the sample was performed by comparing the LTPRI and the mass spectra obtained for the sample with the LTPRI reported in the literature and the mass spectra in NIST, as shown in Table 1.

The quantitative analysis was performed on a Thermo Scientific Trace 1310 gas chromatograph (USA) equipped with a flame ionization detector (FID) and ChromQuest software. The chromatographic separation was performed under the same chromatographic conditions described for the GC-IT/MS, including the same stationary phase. Quantification was carried out by internal standardization, using 4-methyl-2-pentanol as the internal standard, according to a methodology previously developed and validated in our laboratory. ${ }^{11}$ The odor activity value (OAV) was calculated as the ratio between the concentration of each compound and the threshold described in the literature (Table 1).

\section{Determination of phenolic compounds and antioxidant activity}

\section{Spectrophotometric analysis}

The content of total polyphenols was determined using the FolinCiocalteu method ${ }^{12}$ with gallic acid as the standard. The evaluation 
of the in vitro antioxidant activity was performed through the assessment of the capture of the free radicals DPPH, ${ }^{13}$ based on the measurement of the antioxidant scavenging ability of 2.2-diphenyl1-prcrylhydrazul, and ABTS, ${ }^{14}$ by decolorization of the 2,2'-azinobis-(3-ethylbenzothiazoline-6-sulfonic acid).

\section{Quantitative analysis of phenolic compounds}

The determination of phenolic compounds was performed using a high-performance liquid chromatograph (Varian USA) equipped with a quaternary pump system (Pro Star 230), UV-Vis detector (Pro Star 310) and Star Workstation software, version 6.0. The stationary phase was composed of a $\mathrm{C}_{18}$ reverse phase pre-column and column (4.6 mm x $250 \mathrm{~mm}$ x $5 \mu \mathrm{m}$ particle size) (Phenomenex, Torrance,
CA, USA). The phenolic compounds were determined according to the methodology of Cadahía et al. ${ }^{15}$ with modifications. The mobile phase A consisted of ultra-pure water and acetic acid (98:2 v/v) and the mobile phase $\mathrm{B}$ of ultrapure water, acetic acid and acetonitrile $(58: 2: 40 \mathrm{v} / \mathrm{v} / \mathrm{v})$. Elution was performed by linear gradient: $0-80 \%$ solvent B for $55 \mathrm{~min}, 80-100 \%$ B for $15 \mathrm{~min}, 100-0 \%$ B for $10 \mathrm{~min}$. A flow rate of $0.9 \mathrm{~mL} \mathrm{~min}^{-1}$ was used. Detection was performed at 280 $\mathrm{nm}$. The identification of the phenolic compounds was performed by comparing the peak retention times of the samples and the standards, and the quantification was carried out by external standardization. The analytical method was validated considering to the Harmonized Guidelines for Single Laboratory Validation of Methods of Analysis. ${ }^{16}$

Table 1. Volatile compounds identified in Merlot red wines from the regions of Água Doce, Campos Novos and Tangará, harvests 2012, 2013 and 2014, with their respective retention times, retention indexes, identification methods, odor descriptors and thresholds

\begin{tabular}{|c|c|c|c|c|c|c|}
\hline $\begin{array}{l}\text { Retention } \\
\text { time }\end{array}$ & Compound & $\begin{array}{c}\text { LTPRI } \\
\text { calculated }\end{array}$ & $\begin{array}{c}\text { LTPRI } \\
\text { literature }\end{array}$ & Identification method & Odor descriptors & $\begin{array}{c}\text { Threshold } \\
\left(\mu \mathrm{g} \mathrm{L}^{-1}\right)\end{array}$ \\
\hline 6.312 & Methyl acetate & 601 & $\mathrm{NF}$ & MS & $\mathrm{NF}$ & $\mathrm{NF}$ \\
\hline 7.592 & Ethyl acetate & 621 & $620^{\mathrm{a}}$ & STD, MS & Solvent $^{\mathrm{b}}$, fruity ${ }^{\mathrm{c}, \mathrm{d}}$, balsamic ${ }^{\mathrm{d}}$ & $12000^{\mathrm{e}}$ \\
\hline 13.689 & Ethyl butanoate & 787 & $799^{a}$ & STD, MS & Fruity ${ }^{\mathrm{b}, \mathrm{fg}, \mathrm{g}}$, strawberryg,h & $400^{\mathrm{e}}$ \\
\hline 14.558 & Isoamyl acetate & 825 & $855^{\mathrm{a}}$ & STD, MS & Banana $^{\text {c,d,f,g,h }}$ & $30^{1}$ \\
\hline 15.408 & Ethyl 2-methylbutanoate & 841 & $850^{1}$ & STD, MS & Strawberry ${ }^{\mathrm{f}}$, sweet fruits ${ }^{\mathrm{d}, \mathrm{g}}$ & $18^{1}$ \\
\hline 17.636 & Ethyl isovalerate & 850 & $853^{\mathrm{a}}$ & STD, MS & Fruity, apple ${ }^{g}$ & $1^{\mathrm{e}}$ \\
\hline 17.759 & Ethyl hexanoate & 931 & $917^{\mathrm{j}}$ & STD, MS & $\begin{array}{l}\text { Fruity }{ }^{\mathrm{b}, \mathrm{fh}}, \text { green apple }^{\mathrm{c}, \mathrm{ff}, \mathrm{h}}, \text { strawberry }^{\mathrm{f}}, \\
\text { spices and anise }\end{array}$ & $14^{1}$ \\
\hline 18.316 & 1-hexanol & 1002 & $990^{\mathrm{j}}$ & STD, MS & $\begin{array}{l}\text { Herbaceous, fatty }{ }^{\mathrm{i}} \text {, resinous }{ }^{\mathrm{k}} ; \text { floral, } \\
\text { green, cut grass }\end{array}$ & $110^{\mathrm{e}}$ \\
\hline 24.715 & Hexyl acetate & 1003 & $1014^{\mathrm{a}}$ & STD, MS & Fruity, herbs $^{\mathrm{i}}$, apple $^{\mathrm{f}, \mathrm{h}}$, pear $^{\mathrm{d}, \mathrm{g}, \mathrm{h}}$, cherry $^{\mathrm{d}}$ & $670^{\mathrm{e}}$ \\
\hline 25.428 & 2-propyl-1-heptanol & 1019 & $1016^{\mathrm{j}}$ & MS & Mushrooms ${ }^{j}$ & $\mathrm{NF}$ \\
\hline 25.772 & Furfuryl heptanoate & 1020 & $\mathrm{NF}$ & MS & $\mathrm{NF}$ & $\mathrm{NF}$ \\
\hline 26.292 & 1-propanol & 1029 & $1038^{\mathrm{J}}$ & STD, MS & Ripe fruit, alcohol ${ }^{\mathrm{c}, \mathrm{f}, \mathrm{g}}$ & $306000^{\mathrm{e}}$ \\
\hline 27.790 & 2-ethyl-1-hexanol & 1050 & $1032^{\mathrm{j}}$ & MS & Sweet fruits ${ }^{\mathrm{e}}$, roses, green ${ }^{\mathrm{j}}$ & $8000^{\mathrm{e}}$ \\
\hline 28.926 & Ethyl lactate & 1071 & $1101^{\mathrm{j}}$ & STD, MS & Acid, medicine ${ }^{\mathrm{c}}$, strawberry, raspberry ${ }^{\mathrm{g}}$ & $150000^{\mathrm{e}}$ \\
\hline 31.440 & Ethyl heptanoate & 1079 & $1083^{\mathrm{j}}$ & STD, MS & Fruity, pineapple $^{\mathrm{d}}$ & $2.2^{\mathrm{e}}$ \\
\hline 32.612 & 2,2-dimethyl-1-propanol & 1081 & $1091^{\mathrm{e}}$ & MS & Alcohol, sweet $\mathrm{t}^{\mathrm{j}}$ & $75000^{\mathrm{e}}$ \\
\hline 34.193 & 1-butanol & 1105 & $1113^{\mathrm{k}}$ & MS & Medicine $^{\mathrm{e}}$ & $150000^{\mathrm{e}}$ \\
\hline 34.233 & 2-ethyl-1-pentanol & 1107 & $1107^{\mathrm{j}}$ & MS & Synthetic, balsamic ${ }^{\mathrm{e}}$ & $64000^{e}$ \\
\hline 34.692 & Methyl octanoate & 1108 & $1110^{\mathrm{a}}$ & MS & Fruity, citric $^{\mathrm{e}}$ & $200^{\mathrm{e}}$ \\
\hline 34.978 & 3-hexen-1-ol & 1134 & $1129^{j}$ & MS & Green, fat ${ }^{\mathrm{e}}$ & $1000^{\mathrm{e}}$ \\
\hline 35.057 & Ethyl 2-hydroxy-3-methyl-butanoate & 1141 & $1130^{\mathrm{k}}$ & MS & Pineapple, strawberry, tea, honey & $1000^{\mathrm{e}}$ \\
\hline 35.262 & Thioacetic acid & 1167 & $1163^{\mathrm{j}}$ & MS & Toasty $^{\mathrm{j}}$ & $\mathrm{NF}$ \\
\hline 35.275 & 3-sec-butyl-2-methoxypyrazine & 1181 & $1172^{1}$ & STD, MS & Green pepper, earthy ${ }^{1}$ & $0.002^{1}$ \\
\hline 35.571 & Nonan-2-one & 1184 & $1184^{j}$ & MS & Fruity $^{\mathrm{e}}$ & $41^{\mathrm{e}}$ \\
\hline 38.647 & Linalool oxide & 1185 & $1161^{\mathrm{j}}$ & MS & Floral $^{\mathrm{g}}$ & $25^{1}$ \\
\hline 38.653 & Ethyl octanoate & 1191 & $1192^{\mathrm{a}}$ & STD, MS & Fruity, sweet ${ }^{\mathrm{c}, \mathrm{f}}$,pineapple, pear, floral ${ }^{\mathrm{d}, \mathrm{h}}$ & $580^{\mathrm{e}}$ \\
\hline 38.670 & 2-hexen-1-ol & 1198 & $1228^{\mathrm{k}}$ & MS & Grass, herbaceous $^{\mathrm{e}}$ & $400^{\mathrm{e}}$ \\
\hline 39.741 & 3-methyl-1-butanol & 1202 & $1205^{\mathrm{J}}$ & STD, MS & Burnt, alcohol ${ }^{\mathrm{chh}}$, nail polish, whiskey ${ }^{\mathrm{d}}$ & $30000^{1}$ \\
\hline 40.086 & 1-heptanol & 1205 & $1225^{\mathrm{k}}$ & MS & Herbaceous $^{\mathrm{k}}$ & $200^{\mathrm{e}}$ \\
\hline 40.279 & 2'(trifluoromethyl)-acetophenone & 1207 & $1208^{\mathrm{j}}$ & MS & Floral, almonds $\mathrm{s}^{\mathrm{j}}$ & $\mathrm{NF}$ \\
\hline 40,627 & Citronelal & 1231 & $1229^{\mathrm{k}}$ & STD, MS & Sweet, citric ${ }^{\mathrm{e}}$ & $100^{\mathrm{e}}$ \\
\hline 41.415 & Furfuryl acetate & 1240 & $1238^{\mathrm{j}}$ & STD, MS & Toasty $^{\mathrm{j}}$ & $540^{\mathrm{m}}$ \\
\hline 42.633 & Borneol & 1244 & $1253^{\mathrm{j}}$ & MS & Camphor $^{\mathrm{j}}$ & $\mathrm{NF}$ \\
\hline 43.044 & 2-hydroxy-2-methylbutanoic acid & 1259 & $\mathrm{NF}$ & MS & $\mathrm{NF}$ & $\mathrm{NF}$ \\
\hline 43.206 & 1-decanol & 1273 & $1263^{\mathrm{j}}$ & MS & Sweet, fatty ${ }^{\mathrm{e}}$ & $400^{\mathrm{e}}$ \\
\hline 44.138 & Ethyl nonanoate & 1281 & $1280^{\mathrm{a}}$ & STD, MS & Fruity, floral ${ }^{\mathrm{e}}$ & $1300^{\mathrm{e}}$ \\
\hline 44.400 & 2-ethyl-1-decanol & 1283 & $1265^{\mathrm{i}}$ & MS & Fatty $^{\mathrm{e}}$ & $400^{\mathrm{e}}$ \\
\hline 44.516 & Isobutyric acid & 1283 & $1306^{j}$ & STD, MS & Cheese $^{\mathrm{e}}$ & $200000^{\mathrm{e}}$ \\
\hline 44.751 & 2-hepten-3-ol & 1341 & $1350^{\mathrm{e}}$ & MS & $\mathrm{NF}$ & $\mathrm{NF}$ \\
\hline
\end{tabular}


Table 1. Volatile compounds identified in Merlot red wines from the regions of Água Doce, Campos Novos and Tangará, harvests 2012, 2013 and 2014, with their respective retention times, retention indexes, identification methods, odor descriptors and thresholds (cont.)

\begin{tabular}{|c|c|c|c|c|c|c|}
\hline $\begin{array}{l}\text { Retention } \\
\text { time }\end{array}$ & Compound & $\begin{array}{c}\text { LTPRI } \\
\text { calculated }\end{array}$ & $\begin{array}{c}\text { LTPRI } \\
\text { literature }\end{array}$ & Identification method & Odor descriptors & $\begin{array}{c}\text { Threshold } \\
\left(\mu \mathrm{g} \mathrm{L}^{-1}\right)\end{array}$ \\
\hline 44.844 & 3-octenol & 1364 & $1394^{i}$ & MS & Chesnut flower, mushrooms ${ }^{\mathrm{e}}$ & $1^{\mathrm{e}}$ \\
\hline 45.724 & 1-undecanol & 1379 & $1371^{\mathrm{j}}$ & MS & Tangerine $^{j}$ & $\mathrm{NF}$ \\
\hline 45.921 & Ethyl decanoate & 1388 & $1384^{\mathrm{j}}$ & STD, MS & Fruity, grape ${ }^{\mathrm{e}}$ & $200^{1}$ \\
\hline 45.980 & Ethyl 2-hydroxy-3-methylbutanoate & 1390 & $1399^{\mathrm{e}}$ & MS & Pineapple, strawberry, tea, honey ${ }^{\mathrm{e}}$ & $1000^{\mathrm{e}}$ \\
\hline 46.369 & Furfural & 1453 & $1455^{j}$ & MS & Bread, almonds, sweet ${ }^{j}$ & $14100^{1}$ \\
\hline 46.711 & Isoamyl caproate & 1455 & $1445^{\mathrm{e}}$ & MS & Sweet fruity ${ }^{\mathrm{e}}$ & $1000^{\mathrm{e}}$ \\
\hline 47.139 & Benzaldehyde & 1493 & $1495^{\mathrm{j}}$ & MS & Almonds ${ }^{\mathrm{e}}$ & $2000^{\mathrm{e}}$ \\
\hline 47.315 & Ethyl 3-hydroxy-butanoate & 1536 & $1524^{j}$ & STD, MS & ${\text { Green } \text { grape }^{\mathrm{h}} \text {, marshmallow }}^{\mathrm{j}}$ & $20000^{1}$ \\
\hline 49.169 & Ethyl 2-hydroxy-hexanoate & 1556 & $1542^{\mathrm{e}}$ & MS & Cherry $^{\mathrm{e}}$ & $\mathrm{NF}$ \\
\hline 50.011 & 4-terpineol & 1604 & $1602^{\mathrm{e}}$ & MS & Sweet, herbaceous ${ }^{\mathrm{e}}$ & $250^{\mathrm{e}}$ \\
\hline 50.167 & Methyl benzoate & 1609 & $1600^{\mathrm{j}}$ & MS & Prune, herbaceous, sweet ${ }^{\mathrm{j}}$ & $\mathrm{NF}$ \\
\hline 50.571 & Isoamyl lactate & 1610 & $1615^{\mathrm{e}}$ & MS & $\mathrm{NF}$ & $\mathrm{NF}$ \\
\hline 50.948 & Ethyl furoate & 1612 & $1617^{\mathrm{e}}$ & MS & Balsamice $^{\mathrm{e}}$ & $16000^{\mathrm{e}}$ \\
\hline 51.060 & Butanoic acid & 1619 & $1619^{j}$ & STD, MS & Cheese, rancidity ${ }^{\mathrm{e}}$ & $173^{1}$ \\
\hline 52.212 & Ethyl-methyl succinate & 1623 & $1624^{\mathrm{e}}$ & MS & $\mathrm{NF}$ & $\mathrm{NF}$ \\
\hline 52.330 & Cinnamaldehyde & 1632 & $1631^{j}$ & MS & Cinnamon, paint $\mathrm{t}^{\mathrm{j}}$ & $\mathrm{NF}$ \\
\hline 52.587 & Isovaleric acid & 1666 & $1660^{\mathrm{e}}$ & STD, MS & Sweet, cheese ${ }^{\mathrm{k}}$, rancidity & $3000^{\mathrm{e}}$ \\
\hline 52.810 & Isoamyl octanoate & 1669 & $1668^{\mathrm{e}}$ & MS & Oily, cheese, cream, sweet ${ }^{\mathrm{e}}$ & $152^{\mathrm{e}}$ \\
\hline 53.213 & Furfuryl alcohol & 1670 & $1673^{k}$ & STD, MS & Burnt $^{j}$ & $2000^{1}$ \\
\hline 53.497 & Ethyl benzoate & 1675 & $1664^{\mathrm{e}}$ & MS & Camomile, floral, fruity, celery ${ }^{\mathrm{j}}$ & $56^{\mathrm{e}}$ \\
\hline 54.040 & Diethyl succinate & 1691 & $1690^{\mathrm{e}}$ & STD, MS & Wine $^{\mathrm{c}, \mathrm{d,h}}$, caramel $^{\mathrm{f}}$, fruity $^{\mathrm{d}}$ & $200000^{1}$ \\
\hline 54.711 & Ethyl 9-decenoate & 1700 & $1708^{\mathrm{e}}$ & MS & Roses $^{\mathrm{e}}$ & $100^{\mathrm{e}}$ \\
\hline 55.946 & $\alpha$-terpineol & 1711 & $1713^{\mathrm{e}}$ & STD, MS & Floral, sweet ${ }^{\mathrm{e}}$, anise, mint $^{\mathrm{j}}$ & $250^{1}$ \\
\hline 58.252 & 3-methylthio-1-propanol & 1726 & $1729^{\mathrm{e}}$ & MS & Cooked vegetables ${ }^{\mathrm{e}}$ & $500^{\mathrm{e}}$ \\
\hline 58.608 & Methyl salicylate & 1744 & $1745^{\mathrm{j}}$ & MS & Pepper mint $\mathrm{t}^{\mathrm{j}}$ & $0.1^{\mathrm{m}}$ \\
\hline 58.707 & Furfuryl thioacetate & 1781 & $1785^{j}$ & STD, MS & Toasty $^{\mathrm{j}}$ & $1.5^{\mathrm{m}}$ \\
\hline 59.136 & Ethyl salicylate & 1782 & $1784^{j}$ & MS & Mint $^{j}$ & $\mathrm{NF}$ \\
\hline 59.337 & Phenylethyl acetate & 1790 & $1796^{\mathrm{e}}$ & STD, MS & Roses $^{1}$, floral ${ }^{\mathrm{e}}$, honey ${ }^{\mathrm{g}}$ & $250^{1}$ \\
\hline 59.363 & 2-phenylethyl formate & 1793 & $\mathrm{NF}$ & MS & $\mathrm{NF}$ & $\mathrm{NF}$ \\
\hline 60.401 & Diethyl glutarate & 1806 & $1806^{\mathrm{j}}$ & MS & Cotton candy $\mathrm{y}^{\mathrm{j}}$ & $\mathrm{NF}$ \\
\hline 61.241 & $\alpha$-ionone & 1808 & $1809^{j}$ & STD, MS & Fruity, floral, raspberry, violet ${ }^{\mathrm{h}}$ & $2.6^{1}$ \\
\hline 61.925 & $\beta$-damascenone & 1815 & $1813^{\mathrm{j}}$ & STD, MS & Baked apple $^{\mathrm{l}}$, floral, honey ${ }^{\mathrm{d}, \mathrm{l}}$ & $0.05^{1}$ \\
\hline 62.388 & Ethyl laurate & 1838 & $1835^{\mathrm{e}}$ & STD, MS & Sweet, floral ${ }^{\mathrm{e}}$, waxy, soap ${ }^{\mathrm{h}}$ & $1500^{\mathrm{e}}$ \\
\hline 62.686 & Geraniol & 1849 & $1847^{\mathrm{j}}$ & STD, MS & Roses, geranium ${ }^{\mathrm{c}, \mathrm{g}}$ & $20^{1}$ \\
\hline 62.733 & 2-phenylethanol & 1851 & $1859^{\mathrm{k}}$ & STD, MS & Roses, honey ${ }^{\mathrm{e}, \mathrm{k}}$ & $14000^{1}$ \\
\hline 63.044 & Hexanoic acid & 1869 & $1863^{\mathrm{e}}$ & STD, MS & Cheese, fatty ${ }^{\mathrm{e}}$ & $420^{1}$ \\
\hline 64.386 & Benzyl alcohol & 1871 & $1865^{\mathrm{j}}$ & MS & Sweet, fruity ${ }^{\mathrm{e}}$ & $200000^{1}$ \\
\hline 66.238 & 1-hexadecanol & 1883 & $1870^{\mathrm{j}}$ & MS & Floral, waxy ${ }^{j}$ & $\mathrm{NF}$ \\
\hline 67.360 & 1-dodecanol & 1890 & $1895^{\mathrm{k}}$ & MS & Waxy $^{\mathrm{k}}$ & $1000^{\mathrm{e}}$ \\
\hline 69.071 & Thujopsene (sesquichamene) & 1909 & $\mathrm{NF}$ & MS & $\mathrm{NF}$ & $\mathrm{NF}$ \\
\hline 71.382 & $\beta$-ionone & 1915 & $1912^{\mathrm{j}}$ & STD, MS & Violet $^{\text {d,h,i, }}$, balsamic, roses ${ }^{\mathrm{d}}$ & $0.09^{1}$ \\
\hline 71.915 & Ethyl palmitate & 1994 & $1993^{j}$ & MS & Waxy, fatty & $1500^{\mathrm{e}}$ \\
\hline 71.957 & Ethyl myristate & 1998 & $1999^{j}$ & MS & Lily $^{\mathrm{j}}$ & $\mathrm{NF}$ \\
\hline 72.488 & Nerolidol & 2006 & $2009^{j}$ & MS & Roses, apple, citric, herbaceous ${ }^{\mathrm{e}}$ & $1000^{\mathrm{e}}$ \\
\hline 72.530 & Trans-nerolidol & 2016 & $2010^{j}$ & MS & Waxy $^{j}$ & $\mathrm{NF}$ \\
\hline 72.881 & $\gamma$-nonalactone & 2032 & $2042^{\mathrm{j}}$ & STD, MS & Coconut, peach ${ }^{\mathrm{b}, \mathrm{g} . \mathrm{j}}$ & $30^{1}$ \\
\hline 73.523 & 4-ethylguaiacol & 2033 & $2031^{j}$ & MS & Wood, clove of garlic, smoke ${ }^{e, j}$ & $33^{1}$ \\
\hline 76.672 & Octanoic acid & 2082 & $2083^{j}$ & STD, MS & $\begin{array}{l}\text { Rancidity }{ }^{\mathrm{d}, \mathrm{k}}, \text { sweet, }^{\mathrm{c}} \text { cheese }^{\mathrm{c}} \text {, animal, } \\
\text { spices }^{\mathrm{f}}, \text { unpleasant }^{\mathrm{d}}\end{array}$ & $500^{1}$ \\
\hline 78.453 & Nonanoic acid & 2091 & $2090^{\mathrm{e}}$ & STD, MS & Cheese $^{\mathrm{d}, \mathrm{k}}$, waxy ${ }^{\mathrm{d}}$ & $3000^{\mathrm{e}}$ \\
\hline 78.806 & Tetradecanol & 2092 & $2099^{j}$ & MS & Coconut $^{\mathrm{j}}$ & $\mathrm{NF}$ \\
\hline 80.756 & Ethyl cinnamate & 2140 & $2139^{j}$ & STD, MS & $\begin{array}{l}\text { Honey, cinnamon }{ }^{\mathrm{c}, \mathrm{f}} \text {, floral, strawberry, } \\
\text { plum }^{\mathrm{f}}\end{array}$ & $1.1^{1}$ \\
\hline 81.983 & 4-ethylphenol & 2153 & $2154^{\mathrm{e}}$ & MS & Bitumen, leather $^{1}$ & $440^{1}$ \\
\hline
\end{tabular}


Table 1. Volatile compounds identified in Merlot red wines from the regions of Água Doce, Campos Novos and Tangará, harvests 2012, 2013 and 2014, with their respective retention times, retention indexes, identification methods, odor descriptors and thresholds (cont.)

\begin{tabular}{|c|c|c|c|c|c|c|}
\hline $\begin{array}{l}\text { Retention } \\
\text { time }\end{array}$ & Compound & $\begin{array}{c}\text { LTPRI } \\
\text { calculated }\end{array}$ & $\begin{array}{c}\text { LTPRI } \\
\text { literature }\end{array}$ & Identification method & Odor descriptors & $\begin{array}{c}\text { Threshold } \\
\left(\mu \mathrm{g} \mathrm{L}^{-1}\right)\end{array}$ \\
\hline 82.331 & $\alpha$-bisabolol & 2235 & $2235^{j}$ & MS & Spices, floral ${ }^{\mathrm{j}}$ & $90^{\mathrm{m}}$ \\
\hline 83.270 & Ethyl vanillate & 2247 & $2247^{j}$ & MS & Vanilla, honey $^{1}$ & $3000^{1}$ \\
\hline 87.799 & Decanoic acid & 2279 & $2287^{\mathrm{e}}$ & STD, MS & Unpleasant $^{\mathrm{d}, \mathrm{k}}$, fat, rancidity $^{\mathrm{c}}$, animal ${ }^{\mathrm{f}}$ & $1000^{\mathrm{e}}$ \\
\hline 98.137 & 1-heptadecanol & 2466 & $2461^{\mathrm{e}}$ & MS & NF & NF \\
\hline
\end{tabular}

${ }^{\mathrm{a}}$ ref. $17 ;{ }^{\mathrm{b}}$ ref. $18 ;{ }^{\mathrm{c}}$ ref. $19 ;{ }^{\mathrm{d}}$ ref. $20 ;{ }^{\mathrm{e}}$ ref. $21 ;{ }^{\mathrm{f}}$ ref. $22 ;{ }^{\mathrm{g}}$ ref. $23 ;{ }^{\mathrm{h}}$ ref. $8 ;{ }^{\mathrm{i}}$ ref. $24 ;{ }^{\mathrm{j}}$ ref. $25 ;{ }^{\mathrm{k}}$ ref. $26 ;{ }^{1}$ ref. $27 ;{ }^{\mathrm{m}}$ ref. $28 . \mathrm{NF}=$ not found. STD $=$ mass spectra and retention index are agreement with the volatile compound standard. MS = mass spectra in agreement with the NIST spectral database (considering minimum similarity $70 \%$ ). LTPRI $=$ linear temperature programmed retention index.

\section{Statistical analysis}

Statistical analysis of the data was performed using Statistica v.10 software (Statsoft Inc., Tulsa, OK, USA). Analysis of variance (ANOVA) and Tukey's test were applied to the data to evaluate significant differences between samples.

\section{RESULTS AND DISCUSSION}

\section{Volatile compounds profile of wines}

A total of 95 volatile compounds were identified in the Merlot red wine samples (Table 1), 38 of which were positively identified using commercial standards. The remaining compounds were tentatively identified based on the similarity $(>70 \%)$ between the mass spectra of the compounds in the sample and the NIST library, and by comparative analysis between the calculated retention indexes and the retention indexes available in the literature, in which the values reported for polar polyethylene glycol columns were considered. A maximum deviation of 30 units was observed between the experimental data and the retention index reported in the literature for the compounds isoamyl acetate, ethyl lactate, 2-hexen-1-ol and 3 -octenol. Welke et al. ${ }^{29}$ obtained a maximum deviation of 33 units when comparing experimental retention indexes with those reported in the literature in a study on Brazilian Merlot wines from the Serra Gaúcha region. Only $19 \%$ of the compounds tentatively identified showed deviations greater than ten units when the retention indices were compared.

Of the chemical groups found in the volatile fraction of the Merlot wines, the esters were present in the greatest number (40), followed by alcohols (25), acids (9), terpenes (8), aldehydes (3) and $\mathrm{C}_{13}$-norisoprenoids (3), ketones (2) and phenols (2), methoxypyrazine (1), lactone (1) and sesquiterpene alcohol (1). The predominance of the volatile compounds belonging to the classes of esters, alcohols and acids was previously observed by Welke et al. ${ }^{29}$ and Jiang $e t a l .{ }^{7}$ in Merlot varietal wines. According to the data available in the literature, ${ }^{11,29,30}$ terpene borneol were reported for the first time in Brazilian Merlot wines. Borneol, which has a camphor odor, was previously detected in wines of the Fernão Pires cultivar in a study conducted by Rocha et al. ${ }^{31}$ Compounds such as borneol have been reported to have antifungical, pesticide, antibacterial and antioxidant activities, and contribute to the complexity of the wine's aroma, especially for spicy notes. It acts mainly through the mechanism of synergism with other compounds. ${ }^{31}$

\section{Quantification of volatile compounds and odor activity value (OAV)}

The concentrations of the predominant volatiles found in the Merlot wine samples are shown in Table 2. The OAV (odor activity value) was used to determine which compounds could contribute to the aroma of the wines, since volatile compounds with OAV $>1$ is indicative of a possible perception by the human nose. ${ }^{21}$ The class with the highest number of volatile compounds of importance for the aroma of the wines were esters. The ethyl esters of fatty acids found in the highest concentration in the samples analyzed were ethyl hexanoate (54.85 - $\left.974.43 \mu \mathrm{g} \mathrm{L}^{-1}\right)$, ethyl octanoate $\left(165.45\right.$ - $\left.411.10 \mu \mathrm{g} \mathrm{L}^{-1}\right)$ and ethyl decanoate $\left(50.39-470.43 \mu \mathrm{g} \mathrm{L}^{-1}\right)$. Analysis of variance (ANOVA) was applied to the experimental data considering two factors, region and harvest, and revealed that these factors influenced the content of ethyl esters of fatty acids $(p<0.05)$. Only the ethyl octanoate compound did not show a significant difference between the wines from different harvests. In general, a higher content of this class of esters was observed in the 2014 harvest (ethyl hexanoate being an exception). The final concentration of ethyl esters of fatty acids in wines is dependent on the reactions that occur during alcoholic fermentation, culminating in the formation, volatilization and hydrolysis of the esters. Ethyl hexanoate, for example, is derived from the modification of $\mathrm{C}_{6}$ compounds by yeast and its production is dependent on the yeast cell growth rate, which varies according to both the yeast strain and the conditions of the fermentation medium. Also, the concentration of esters in wine is regulated by the ability to release the ethyl esters through the yeast cell membrane. Only 8 to $17 \%$ of the long chain esters present, such as ethyl decanoate, are released into the wine during alcoholic fermentation and therefore their content is usually lower than that of short chain esters. ${ }^{22}$ Ethyl hexanoate presented the highest OAV (3.92 - 69.6), contributing to the aromas of green apple, strawberry and spices ${ }^{8,18,19,22}$ primarily in the case of the wines from Campos Novos. For ethyl decanoate, which has a fruity grape aroma, ${ }^{21}$ the OAV ranged from 0.25 to 1.85 , and it was notably present in the Tangará wines. Ethyl octanoate presented $\mathrm{OAV}<1$ for all samples analyzed and, therefore, it does not contribute significantly to the aroma of the samples.

The higher alcohol acetates found in the largest proportions were ethyl acetate $\left(1552.82\right.$ - $\left.5883.48 \mu \mathrm{g} \mathrm{L}^{-1}\right)$, isoamyl acetate (66.82 - $\left.250.31 \mu \mathrm{g} \mathrm{L}^{-1}\right)$ and phenylethyl acetate $\left(28.91-308.41 \mu \mathrm{g} \mathrm{L}^{-1}\right)$. Isoamyl acetate, with a banana aroma ${ }^{19,20,22,23}$ and phenylethyl acetate, with roses and honey aromas ${ }^{23,27}$ presented OAV $>1$. Analysis of variance (ANOVA $p<0.05$ ) showed that the content of the abovementioned compounds is influenced by the factors harvest and region. These compounds were found to be more concentrated in wines from the Tangará region. The production of acetates from higher alcohols is particularly affected by the fermentation temperature, nutrient content in the must and the yeast strain employed. The dynamic equilibrium between acetates and their corresponding acids and alcohols is dependent on the ratio of carbon to nitrogen available in the fermentation medium. ${ }^{22}$ Considering that in this study the fermentation conditions were the same for all wines, the observed differences could be attributed to the nutrient availability in the must, which is impacted by the terroir in which the grapes are produced. 
Table 2. Concentrations of volatile compounds $\left(\mu \mathrm{g} \mathrm{L}^{-1}\right)$ in Merlot red wines from harvests 2012, 2013 and 2014, produced in the regions Água Doce, Campos Novos and Tangará, Santa Catarina State, Brazil. Results expressed as mean (RSD)

\begin{tabular}{|c|c|c|c|c|c|c|c|c|c|}
\hline \multirow{3}{*}{ Compounds } & \multicolumn{9}{|c|}{ Region } \\
\hline & \multicolumn{3}{|c|}{ Água Doce } & \multicolumn{3}{|c|}{ Campos Novos } & \multicolumn{3}{|c|}{ Tangará } \\
\hline & 2012 & 2013 & 2014 & 2012 & 2013 & 2014 & 2012 & 2013 & 2014 \\
\hline Ethyl butanoate & $<5.82^{\mathrm{c}}$ & $69.78^{\mathrm{b}}(1.68)$ & $138.87^{\mathrm{a}}(3.23)$ & $55.86^{\mathrm{b}}(8.86)$ & $17.65^{\mathrm{bc}}(2.37)$ & $137.58^{\mathrm{a}}(0.12)$ & $<5.82^{\mathrm{c}}$ & $<5.82^{\mathrm{c}}$ & $63.73^{b}(4.99)$ \\
\hline Ethyl hexanoate & $95.19^{c}(2.82)$ & $102.04^{\mathrm{c}}(7.46)$ & $121.33^{\mathrm{c}}(2.31)$ & $120.98^{\mathrm{c}}(1.62)$ & $974.43^{\mathrm{a}}(3.53)$ & $490.01^{b}(2.62)$ & $54.85^{\mathrm{c}}(5.10)$ & $104.90^{c}(8.37)$ & $114.19^{c}(1.28)$ \\
\hline Ethyl heptanoate & nd & nd & nd & $27.39^{\mathrm{a}}(7.51)$ & nd & nd & nd & nd & nd \\
\hline Ethyl octanoate & $165.45^{\mathrm{b}}(7.00)$ & $219.55^{\mathrm{b}}(2.31)$ & $284.96^{\mathrm{ab}}(2.18)$ & $411.10^{\mathrm{a}}(1.97)$ & $254.16^{\mathrm{ab}}(7.94)$ & $244.72^{\text {ab }}(3.78)$ & $226.56^{\mathrm{b}}(7.99)$ & $321.06^{\mathrm{ab}}(1.87)$ & $204.82^{\mathrm{b}}(1.48)$ \\
\hline Ethyl nonanoate & $<0.31^{\mathrm{c}}$ & $<0.31^{\mathrm{c}}$ & $<0.31^{\mathrm{c}}$ & $<0.31^{\mathrm{c}}$ & $<0.31^{\mathrm{c}}$ & $9.86^{\mathrm{a}}(1.61)$ & $5.14^{\mathrm{b}}(7.20)$ & $<0.31^{\mathrm{c}}$ & $5.73^{b}(1.64)$ \\
\hline Ethyl decanoate & $50.39^{\mathrm{c}}(2.33)$ & $88.25^{\text {bc }}(0.92)$ & $196.80^{\mathrm{bc}}(7.68)$ & $203.36^{\text {bc }}(8.32)$ & $206.79^{\text {bc }}(1.47)$ & $123.10^{\text {bc }}(9.50)$ & $58.48^{\mathrm{c}}(3.87)$ & $273.76^{\mathrm{b}}(0.23)$ & $470.43^{\mathrm{a}}(2.16)$ \\
\hline Ethyl dodecanoate & $<6.28^{\mathrm{c}}$ & $<6.28^{c}$ & $9.05^{\mathrm{a}}(1.13)$ & $20.29^{b}(4.14)$ & $<6.28^{\mathrm{c}}$ & $<6.28^{\mathrm{c}}$ & $<6.28^{c}$ & $<6.28^{\mathrm{c}}$ & $21.67^{\mathrm{b}}(8.73)$ \\
\hline Ethyl acetate & $3694.83^{\text {cd }}(7.15)$ & $5883.48^{a}(6.26)$ & $1730.46^{\mathrm{de}}(2.21)$ & $1552.82^{\mathrm{e}}(2.62)$ & $\begin{array}{c}2966.74^{\text {bde }} \\
(2.19)\end{array}$ & $\begin{array}{c}2657.86^{\text {cde }} \\
(2.90)\end{array}$ & $5550.04^{\mathrm{a}}(6.05)$ & $4312.99^{\mathrm{ab}}(1.20)$ & $\begin{array}{c}3282.75^{\mathrm{bcd}} \\
\quad(1.86)\end{array}$ \\
\hline Furfuryl acetate & nd & nd & nd & $<67.00^{\mathrm{a}}$ & nd & $<67.00^{\mathrm{a}}$ & nd & nd & nd \\
\hline Hexyl acetate & $25.69^{\mathrm{a}}(0.25)$ & nd & nd & nd & nd & nd & nd & nd & nd \\
\hline Isoamyl acetate & $73.62^{\mathrm{b}}(5.56)$ & $74.75^{\mathrm{b}}(2.95)$ & $81.07^{\mathrm{b}}(1.62)$ & $83.04^{\mathrm{b}}(1.51)$ & $75.59^{\mathrm{b}}(1.20)$ & $89.36^{\mathrm{b}}(8.04)$ & $66.82^{\mathrm{b}}(8.94)$ & $82.44^{b}(5.08)$ & $250.31^{\mathrm{a}}(9.00)$ \\
\hline Phenylethyl acetate & $28.91^{\mathrm{d}}(2.70)$ & $114.69^{\mathrm{bc}}(1.31)$ & $35.71^{\mathrm{d}}(1.69)$ & $70.86^{\mathrm{cd}}(1.31)$ & $80.09^{\mathrm{cd}}(2.07)$ & $<28.06^{\mathrm{d}}$ & $161.22^{\mathrm{b}}(2.62)$ & $296.81^{\mathrm{a}}(8,39)$ & $308.41^{\mathrm{a}}(8.41)$ \\
\hline Ethyl 2-methylbutanoate & $127.22^{\mathrm{b}}(2.21)$ & $<28.00^{\mathrm{d}}$ & $<28.00^{\mathrm{d}}(3.14)$ & $175.38^{\mathrm{a}}(2.09)$ & $87.82^{\mathrm{c}}(9.29)$ & $<28.00^{\mathrm{d}}$ & $<28.00^{\mathrm{d}}$ & $<28.00^{\mathrm{d}}$ & $<28.00^{\mathrm{d}}$ \\
\hline Ethyl isovalerate & $354.38^{\mathrm{b}}(2.04)$ & $366.96^{\mathrm{b}}(1.90)$ & $275.32^{\mathrm{b}}(1.98)$ & $375.30^{\mathrm{b}}(8.30)$ & $351.64^{\mathrm{b}}(4.66)$ & $659.71^{\mathrm{a}}(3.03)$ & $<15.04^{\mathrm{c}}$ & $<15.04^{\mathrm{c}}$ & $<15.04^{\mathrm{c}}$ \\
\hline Diethyl succinate & $\begin{array}{c}13199.38^{\mathrm{bc}} \\
(1.88)\end{array}$ & $\begin{array}{c}15950.47^{\mathrm{b}} \\
(3.69)\end{array}$ & $3674.91^{\mathrm{d}}(6.71)$ & $\begin{array}{c}24516.77^{\mathrm{a}} \\
\quad(1.23)\end{array}$ & $7858.45^{\text {cd }}(2.15)$ & $\begin{array}{c}12239.90^{\mathrm{bc}} \\
(2.43)\end{array}$ & $\begin{array}{l}25271.90^{\mathrm{a}} \\
\quad(8.40)\end{array}$ & $\begin{array}{c}18259.38^{b} \\
(1.41)\end{array}$ & $\begin{array}{c}12759.54^{\mathrm{bc}} \\
(6.90)\end{array}$ \\
\hline Ethyl lactate & $<10.02^{\mathrm{d}}$ & $\begin{array}{c}25633.24^{\mathrm{a}} \\
(2.35)\end{array}$ & $<10.02^{\mathrm{d}}$ & $<10.02^{\mathrm{d}}$ & $<10.02^{\mathrm{d}}$ & $<10.02^{\mathrm{d}}$ & $334.88^{\mathrm{d}}(7.69)$ & $6267.35^{\mathrm{c}}(1.07)$ & $\begin{array}{c}10058.30^{\mathrm{b}} \\
(4.06)\end{array}$ \\
\hline Ethyl cinnamate & $<4.36^{\mathrm{d}}$ & $54.99^{\mathrm{b}}(1.71)$ & $<4.36^{\mathrm{d}}$ & $<4.36^{\mathrm{d}}$ & $63.52^{\mathrm{a}}(2.09)$ & $<4.36^{\mathrm{d}}$ & $<4.36^{\mathrm{d}}$ & $26.02^{\mathrm{c}}(9.79)$ & $<4.36^{\mathrm{d}}$ \\
\hline 3-methyl 1-butanol & $<5.06^{\mathrm{d}}$ & $5130.33^{\mathrm{c}}(1.38)$ & $<5.06^{\mathrm{d}}$ & $<5.06^{\mathrm{d}}$ & $6343.24^{\mathrm{b}}(2.64)$ & $<5.06^{\mathrm{d}}$ & $5785.29^{\mathrm{bc}}(4.15)$ & ) $8298.84^{\mathrm{a}}(5.40)$ & $<5.06^{\mathrm{d}}$ \\
\hline 1-propanol & $<5.03^{\mathrm{b}}$ & $<5.03^{\mathrm{b}}$ & $<5.03^{\mathrm{b}}$ & $<5.03^{\mathrm{b}}$ & $<5.03^{\mathrm{b}}$ & $7383.87^{\mathrm{a}}(3.34)$ & $<5.03^{\mathrm{b}}$ & $<5.03^{\mathrm{b}}$ & $374.72^{\mathrm{a}}(1.25)$ \\
\hline Furfuryl alcohol & $335.11^{\mathrm{bc}}(1.57)$ & $973.54^{b}$ & $<5.09^{d}$ & $529.83^{\text {bc }}(1.33)$ & $<5.09^{\mathrm{d}}$ & $<5.09^{\mathrm{d}}$ & $<5.09^{\mathrm{d}}$ & $1578.29^{\mathrm{a}}(2.22)$ & $<5.09^{\mathrm{d}}$ \\
\hline 1-hexanol & $199.74^{b}(1.96)$ & $209.33^{\mathrm{b}}(2.54)$ & $152.74^{\mathrm{bc}}(2.02)$ & $183.00^{\text {bc }}(0.23)$ & $160.55^{\text {bc }}(1.33)$ & $165.76^{\text {bc }}(2.63)$ & $113.31^{\mathrm{c}}(1.29)$ & $140.34^{\mathrm{bc}}(0.63)$ & $424.41^{\mathrm{a}}(4.43)$ \\
\hline 2-phenylethanol & $\begin{array}{c}40806.29^{b} \\
(2.08)\end{array}$ & $\begin{array}{c}41762.51^{\mathrm{b}} \\
(4.78)\end{array}$ & $\begin{array}{c}37141.63^{b} \\
(1.42)\end{array}$ & $\begin{array}{c}82741.04^{\mathrm{a}} \\
(2.95)\end{array}$ & $\begin{array}{c}63690.00^{\mathrm{ab}} \\
(1.44)\end{array}$ & $\begin{array}{c}61635.22^{\mathrm{ab}} \\
(2.73)\end{array}$ & $\begin{array}{c}78706.68^{\mathrm{a}} \\
(1.03)\end{array}$ & $\begin{array}{c}89854.11^{\mathrm{a}} \\
(1.50)\end{array}$ & $\begin{array}{c}75619.16^{\mathrm{a}} \\
(8.02)\end{array}$ \\
\hline Propanoic acid & nd & nd & nd & nd & nd & nd & nd & nd & $254.35^{\mathrm{a}}(2.47)$ \\
\hline Butanoic acid & nd & nd & nd & nd & nd & $527.18^{\mathrm{a}}(2.43)$ & nd & nd & nd \\
\hline Hexanoic acid & $266.41^{\mathrm{b}}(2.02)$ & $<31.13^{\mathrm{c}}$ & $217.25^{\mathrm{b}}(5.38)$ & $<31.13^{\mathrm{c}}$ & $<31.13^{\mathrm{c}}$ & $<31.13^{\mathrm{c}}$ & $<31.13^{\mathrm{c}}$ & $<31.13^{\mathrm{c}}(1.67)$ & $852.37^{\mathrm{a}}(8.61)$ \\
\hline Octanoic acid & $<5.00^{\mathrm{d}}$ & $5988.99^{\mathrm{c}}(3.57)$ & $\begin{array}{c}11403.43^{\mathrm{ab}} \\
(2.11)\end{array}$ & $193.83^{\mathrm{d}}(1.67)$ & $8254.89^{\mathrm{bc}}(6.10)$ & $1365.27^{d}(2.74)$ & $6185.59^{\mathrm{c}}(8.21)$ & $5716.23^{c}(1.46)$ & $\begin{array}{l}14536.01^{\mathrm{a}} \\
(8.05)\end{array}$ \\
\hline Nonanoic acid & nd & nd & $<31.72^{\mathrm{a}}$ & nd & nd & nd & nd & nd & nd \\
\hline Decanoic acid & $<32.03^{\mathrm{d}}$ & $<32.03^{\mathrm{d}}$ & $<32.03^{\mathrm{d}}$ & $<32.03^{\mathrm{d}}$ & $190.84^{\mathrm{b}}(5.23)$ & $39.08^{\mathrm{c}}(1.46)$ & $<32.03^{\mathrm{d}}$ & $<32.03^{\mathrm{d}}$ & $289.76^{\mathrm{a}}(3.33)$ \\
\hline Isobutyric acid & $6718.61^{\mathrm{bc}}(3.03)$ & $8330.71^{\mathrm{b}}(8.23)$ & $8592.77^{\mathrm{b}}(2.49)$ & nd & $3135.42^{\mathrm{cd}}(2.87)$ & $5740.87^{\text {bc }}(1.97)$ & $8102.94^{b}(1.17)$ & $5758.10^{\text {bc }}(1.28)$ & $\begin{array}{c}15323.06^{\mathrm{a}} \\
(4.50)\end{array}$ \\
\hline Isovaleric acid & nd & $92.55^{\mathrm{a}}(1.31)$ & $801.01^{\mathrm{a}}(2.87)$ & nd & $385.59^{\mathrm{a}}(1.22)$ & $5347.30^{\mathrm{b}}(2.26)$ & $2251.68^{c}(6.72)$ & $287.16^{\mathrm{a}}(2.07)$ & $6265.72^{\mathrm{b}}(1.25)$ \\
\hline Geraniol & nd & nd & nd & nd & nd & nd & nd & nd & $23.88^{\mathrm{a}}(2.91)$ \\
\hline$\alpha$-terpineol & $89.50^{\mathrm{a}}(2.73)$ & $<10.76^{c}$ & $<10.76^{c}$ & $26.74^{\text {bc }}(2.36)$ & $17.39^{\mathrm{bc}}(3.46)$ & $<10.76^{c}$ & $21.45^{\text {bc }}(1.45)$ & $35.91^{\mathrm{b}}(1.60)$ & $<10.76^{\mathrm{c}}$ \\
\hline Citronelal & nd & nd & nd & nd & nd & nd & nd & nd & $43.70^{\mathrm{a}}(2.69)$ \\
\hline$\gamma$-nonalactone & nd & nd & nd & nd & nd & nd & nd & nd & $703.56^{\mathrm{a}}(8.64)$ \\
\hline$\beta$-damascenone & $13.66^{\mathrm{a}}(3.79)$ & $<3.05^{\mathrm{b}}$ & $15.69^{\mathrm{a}}(6.73)$ & $<3.05^{\mathrm{b}}$ & $<3.05^{\mathrm{b}}$ & $10.91^{\mathrm{a}}(2.52)$ & $<3.05^{\mathrm{b}}$ & $<3.05^{\mathrm{b}}$ & $14.93^{\mathrm{a}}(1.18)$ \\
\hline$\beta$-ionone & $<1.71^{\mathrm{a}}$ & $<1.71^{\mathrm{a}}$ & $<1.71^{\mathrm{a}}$ & $<1.71^{\mathrm{a}}$ & $<1.71^{\mathrm{a}}$ & $<1.71^{\mathrm{a}}$ & $<1.71^{\mathrm{a}}$ & $<1.71^{\mathrm{a}}$ & $<1.71^{\mathrm{a}}$ \\
\hline$\alpha$-ionone & $<2.61^{\mathrm{b}}$ & $<2.61^{\mathrm{b}}$ & $<2.61^{\mathrm{b}}$ & $<2.61^{\mathrm{b}}$ & $<2.61^{\mathrm{b}}$ & $24.35^{\mathrm{a}}(2.55)$ & $<2.61^{\mathrm{b}}$ & $<2.61^{\mathrm{b}}$ & $<2.61^{\text {b }}$ \\
\hline
\end{tabular}

Different letters on the same line indicate a significant difference at the $p<0.05$ level. nd $=$ not detected. The limits of detection for not detected compounds: ethyl heptanoate $\left(0.10 \mu \mathrm{L}^{-1}\right)$, furfuryl acetate $\left(23.09 \mu \mathrm{L}^{-1}\right)$, hexyl acetate $\left(8.75 \mu \mathrm{L}^{-1}\right)$, propanoic acid $\left(17.02 \mu \mathrm{L}^{-1}\right)$, butanoic acid $\left(12.17 \mu \mathrm{L}^{-1}\right)$, nonanoic acid $\left(11.57 \mu \mathrm{L}^{-1}\right)$, isobutyric acid $\left(2.74 \mu \mathrm{L}^{-1}\right)$, isovaleric acid $\left(3.15 \mu \mathrm{L}^{-1}\right)$, geraniol $\left(3.82 \mu \mathrm{L}^{-1}\right)$, citronelal $\left(1.51 \mu \mathrm{L}^{-1}\right), \gamma$-nonalactone $\left(4.65 \mu \mathrm{L}^{-1}\right)$.

The other notable classes of esters in the volatile compounds profile were ethyl cinnamate, ethyl 2-methylbutanoate, ethyl isovalerate, diethyl succinate and ethyl lactate. The harvest and region were found to be determinant factors for the content of these esters when ANOVA $(p<0.05)$ was applied. Higher concentrations of ethyl lactate and ethyl cinnamate were determined in the wines of 
the 2013 harvest, from the regions of Água Doce and Campos Novos, respectively. Higher concentrations of ethyl 2-methylbutanoate were observed in wines from Campos Novos, 2012 harvest, while higher levels of diethyl succinate were found in samples from Campos Novos and Tangará, 2012 harvest. The concentration of esters of branched chains is usually significant in red wines, since maceration provides greater extraction of the precursor amino acids of these compounds. ${ }^{32}$ Of this class of esters, only ethyl 2-methylbutanoate (OAV of 3.63 to 9.74), ethyl isovalerate (OAV of 275.32 to 659.71) and ethyl cinnamate (OAV of 20.62 to 57.74) have an impact on the aroma of the samples analyzed.

Furfuryl alcohol, 1-propanol, 3-methyl-1-butanol, 1-hexanol and 2-phenylethanol were the alcohols found in the samples analyzed. Analysis of variance (ANOVA $p<0.05$ ) revealed that the content of higher alcohols is influenced by the region and harvest, except for 2-phenylethanol, where only the region is considered a determinant factor for the concentration differences. With a roses aroma, ${ }^{21,26}$ 2-phenylethanol (OAV 2.65 to 6.42) showed a higher content in wines from Campos Novos and Tangará. The concentration of this alcohol in wine is dependent on the relationship between the carbon and nitrogen of the must, and its production during the fermentation process is inversely proportional to the free amino acids content available, that is, it is strongly determined by the chemical composition of the grapes. ${ }^{33}$ The concentration of 1-hexanol is usually significant in macerated wines, since precursors of $\mathrm{C}_{6}$ compounds, such as linoleic and linolenic acids, are extracted from the grapes during the maceration of the peel. ${ }^{22}$ This compound, which contributes to the herbaceous aroma of cut grass ${ }^{24}$ presented a variable OAV (1.27 to 3.86) and was present at higher concentrations in wines from the region of Tangará produced from the 2014 harvest.

Eight fatty acids were detected in the Merlot wine samples, but only four of them can be perceived by the human nose. The OAV values were: isovaleric acid 1.78 to 2.09; butanoic acid 3.50; hexanoic acid 2.27; and octanoic acid 2.73 to 29.07 . The production of fatty acids is dependent on the composition of the must and the fermentation conditions. When the sum of $\mathrm{C}_{6}$ to $\mathrm{C}_{10}$ fatty acids is greater than $10 \mathrm{mg} \mathrm{L}^{-1}$, these compounds have an adverse impact on the aroma of wines. $^{7}$ This situation was observed for wines from the three regions studied, especially those produced in Tangará from the 2014 harvest.
Geraniol $(\mathrm{OAV}=1.36)$, citronelal $(\mathrm{OAV}=0.44)$ and $\gamma$-nonalactone $(\mathrm{OAV}=29.07)$ were quantified only in the wines of the 2014 harvest produced with grapes grown in Tangará. These compounds contribute, respectively, to the aromas of geranium and coconut. ${ }^{19,23}$ The compound $\alpha$-ionone was found in a concentration above the limit of quantification of the method only in Merlot wine from Campos Novos, harvest 2014, with an OAV of 9.36, while $\beta$-damascenone presented the highest OAV values obtained in this study, ranging from 2182 to 3139. $\mathrm{C}_{13}$-norisoprenoids, such as $\alpha$-ionone and $\beta$-damascenone, are formed through the oxidative cleavage of carotenoids, which occurs during grape maturation. ${ }^{22} \beta$-damascenone is a powerful odorant due to the low threshold, presenting aromas of cooked apple, flowers and honey, ${ }^{20,27}$ while $\alpha$-ionone has raspberry and violet aromas. ${ }^{8}$ The values for the $\beta$-damascenone concentration found in this study were higher than those observed in the literature for Merlot wines. ${ }^{34}$ Similar concentrations of $\beta$-damascenone were previously observed by Qian et al. $^{35}$ in Merlot wines produced from grapes grown under partial vineyard irrigation conditions.

\section{Phenolic content and antioxidant activity}

The results for the determination of phenolic compounds in samples of Merlot wines are reported in Table 3 and the validation data of the analytical methodology are shown in Table 1S. ANOVA was applied to the experimental data considering two factors, region and harvest, and revealed that these factors influenced the content of free hydroxycinnamic acids $(p<0.05)$. Regarding the region of grape production, the Campos Novos region presented a higher content of caffeic acid, coumaric acid and ferulic acid. It was observed that the highest levels of caffeic acid and coumaric acid were obtained in the 2014 harvest, while for ferulic acid the harvest of 2012 had the highest values. Similar results were obtained by Cadahía et al., ${ }^{15}$ which indicates that the decrease observed in the concentration of cinnamic acids in wines with a longer aging time may be due to the processes of oxidative condensation and copigmentation. A hypothesis that could explain the result obtained for the ferulic acid in Campos Novos wines is the hydrolysis of hydroxycinnamates during aging of the wine in bottles, as previously observed by Gris et al. ${ }^{5}$

Table 3. Phenolic composition (mg L ${ }^{-1}$ ) of Merlot red wines, 2012, 2013 and 2014 harvests, from the regions of Água Doce, Campos Novos and Tangará, Santa Catarina State, Brazil. Results expressed as mean (RSD)

\begin{tabular}{|c|c|c|c|c|c|c|c|c|c|}
\hline \multirow{3}{*}{ Compounds } & \multicolumn{9}{|c|}{ Region } \\
\hline & \multicolumn{3}{|c|}{ Água Doce } & \multicolumn{3}{|c|}{ Campos Novos } & \multicolumn{3}{|c|}{ Tangará } \\
\hline & 2012 & 2013 & 2014 & 2012 & 2013 & 2014 & 2012 & 2013 & 2014 \\
\hline Caffeic acid & $4.15^{\mathrm{c}}(3.97)$ & $<0.06^{\mathrm{f}}$ & $12.21^{\mathrm{a}}(3.19)$ & $7.55^{\mathrm{e}}(4.57)$ & $10.19^{\mathrm{b}}(0.54)$ & $16.27^{\mathrm{d}}(2.98)$ & $<0.64^{\mathrm{f}}$ & $6.69^{\mathrm{e}}(3.59)$ & $17.32^{\mathrm{d}}(2.51)$ \\
\hline$p$-coumaric acid & $0.83^{\mathrm{e}}(7.78)$ & $<0.10^{\mathrm{e}}$ & $3.13^{\mathrm{ab}}(4.15)$ & $1.65^{\mathrm{cd}}(4.53)$ & $3.00^{\mathrm{abc}}(2.83)$ & $2.47^{\mathrm{bcd}}(4.05)$ & $<0.10^{\mathrm{e}}$ & $2.12^{\mathrm{cd}}(1.98)$ & $3.58^{\mathrm{a}}(2.79)$ \\
\hline Ferulic acid & $<0.05^{\mathrm{d}}$ & $<0.05^{\mathrm{d}}$ & $1.47^{\mathrm{bc}}(4.41)$ & $11.29^{\mathrm{a}}(2.39)$ & $<0.05^{\mathrm{d}}$ & $0.97^{\mathrm{c}}(6.18)$ & $<0.05^{\mathrm{d}}$ & $0.13^{\mathrm{d}}(3.70)$ & $1.98^{\mathrm{b}}(3.03)$ \\
\hline Vanillic acid & $0.14^{\mathrm{d}}(1.03)$ & $8.99^{\mathrm{b}}(1.61)$ & $2.82^{\mathrm{cd}}(4.61)$ & $5.43^{\mathrm{c}}(5.98)$ & $4.03^{\mathrm{c}}(1.74)$ & $3.63^{\mathrm{c}}(6.34)$ & $21.68^{\mathrm{a}}(6.78)$ & $2.76^{\mathrm{cd}}(3.26)$ & $11.07^{\mathrm{b}}(1.53)$ \\
\hline Syringic acid & $<0.11^{\mathrm{f}}$ & $1.50^{\mathrm{e}}(7.33)$ & $<0.11^{\mathrm{f}}$ & $3.35^{\mathrm{c}}(6.27)$ & $4.74^{\mathrm{a}}(0.10)$ & $1.00^{\mathrm{e}}(3.48)$ & $3.99^{\mathrm{b}}(4.55)$ & $2.42^{\mathrm{d}}(4.55)$ & $0.31^{\mathrm{f}}(1.64)$ \\
\hline Protocatechuic acid & $1.86^{\mathrm{c}}(3.48)$ & $2.63^{\mathrm{c}}(2.09)$ & $2.56^{\mathrm{c}}(0.39)$ & $3.21^{\mathrm{c}}(1.01)$ & $8.75^{\mathrm{b}}(2.11)$ & $3.00^{c}(6.15)$ & $2.53^{\mathrm{c}}(1.58)$ & $21.05^{\mathrm{a}}(3.37)$ & $0.77^{\mathrm{c}}(5.80)$ \\
\hline Gallic acid & $9.34^{\mathrm{cd}}(2.89)$ & $7.95^{\mathrm{d}}(2.51)$ & $12.74^{\mathrm{abc}}(3.30)$ & $13.72^{\mathrm{ab}}(6.56)$ & $13.42^{\mathrm{ab}}(1.56)$ & $10.35^{\mathrm{abc}}(1.14)$ & $15.81^{\mathrm{a}}(6.45)$ & $8.20^{\mathrm{d}}(3.11)$ & $10.23^{\mathrm{abc}}(1.76)$ \\
\hline Quercetin & $6.69^{\mathrm{e}}(9.78)$ & $11.13^{\mathrm{de}}(5.16)$ & $24.45^{\mathrm{b}}(0.74)$ & $21.49^{\mathrm{b}}(0.86)$ & $7.46^{\mathrm{e}}(2.74)$ & $14.99^{\mathrm{cd}}(4.73)$ & $30.91^{\mathrm{a}}(8.02)$ & $7.37^{\mathrm{e}}(2.17)$ & $16.10^{\mathrm{c}}(4.41)$ \\
\hline Kaempferol & $0.90^{\mathrm{d}}(6.67)$ & $0.98^{\mathrm{cd}}(1.73)$ & $3.87^{\mathrm{ab}}(2.71)$ & $3.35^{\mathrm{b}}(0.89)$ & $1.40^{\mathrm{cd}}(3.36)$ & $0.71^{\mathrm{d}}(2.25)$ & $4.34^{\mathrm{a}}(2.55)$ & $1.27^{\mathrm{cd}}(2.30)$ & $1.82^{\mathrm{c}}(8.79)$ \\
\hline$(+)$-Catechin & $38.80^{\mathrm{bc}}(0.37)$ & $65.41^{\mathrm{a}}(1.88)$ & $33.88^{\mathrm{bc}}(3.02)$ & $31.80^{\text {bcd }}(3.60)$ & $20.96^{\mathrm{e}}(2.90)$ & $48.04^{\mathrm{b}}(7.75)$ & $66.75^{\mathrm{a}}(1.87)$ & $38.00^{\mathrm{bc}}(1.33)$ & $25.02^{\mathrm{cd}}(1.25)$ \\
\hline (-)-Epicatechin & $11.91^{\mathrm{def}}(1.26)$ & $89.29^{\mathrm{a}}(2.02)$ & $32.60^{\mathrm{bc}}(8.48)$ & $19.83^{\text {cde }}(6.35)$ & $7.53^{\text {ef }}(7.83)$ & $5.78^{\mathrm{f}}(1.43)$ & $8.25^{\mathrm{ef}}(5.60)$ & $22.24^{\mathrm{cd}}(1.40)$ & $37.81^{\mathrm{b}}(1.73)$ \\
\hline Tyrosol & $6.15^{\mathrm{e}}(0.65)$ & $13.80^{\mathrm{bcd}}(0.43)$ & $19.36^{\mathrm{b}}(2.97)$ & $47.32^{\mathrm{a}}(6.48)$ & $46.67^{\mathrm{a}}(5.00)$ & $11.28^{\mathrm{cde}}(3.32)$ & $7.34^{\mathrm{de}}(7.02)$ & 7.63de (1.18) & $18.04^{\mathrm{bc}}(2.47)$ \\
\hline Trans-resveratrol & $0.60^{c}(1.00)$ & $0.58^{\mathrm{c}}(2.99)$ & $0.27^{\mathrm{d}}(3.70)$ & $2.17^{\mathrm{a}}(1.84)$ & $0.61^{\mathrm{c}}(1.38)$ & $0.75^{\mathrm{c}}(9.33)$ & $<0.05^{\mathrm{d}}$ & $0.45^{\mathrm{cd}}(3.30)$ & $0.85^{\mathrm{c}}(7.60)$ \\
\hline
\end{tabular}

Different letters on the same line indicate a significant difference at the $p<0.05$ level. 

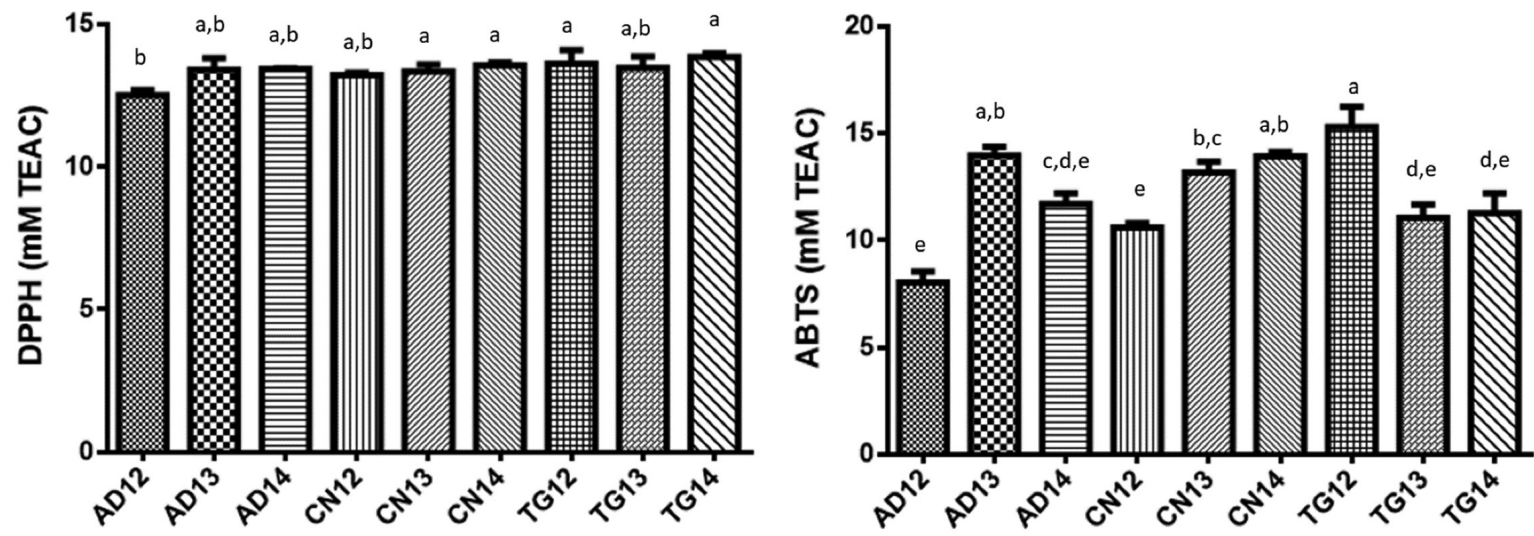

Figure 1. In vitro antioxidant activity evaluated by the capture of free radicals DPPH and ABTS of Merlot wines from Água Doce (AD), Campos Novos (CN) and Tangará (TG) regions, 2012 (12), 2013 (13) and 2014 (14) harvests

For hydroxybenzoic acids, gallic acid was predominant, followed by vanillic and protocatechuic acid in the samples analyzed. The cultivation region influenced the concentration of hydroxybenzoic acids, as determined by ANOVA $(p<0.05)$. Higher contents of vanillic acid and protocatechuic acid were observed for wines produced in Tangará, while the levels of gallic acid and syringic acid were highest for the Campos Novos region.

With regard to flavonols, higher concentrations of quercetin and kaempferol were observed in wines produced in Tangará from the 2012 harvest, when compared to the other regions and harvests $(p$ $<0.05)$. During the aging of the wine, the increase in the content of flavonols in the form of aglycones can be explained by the occurrence of the hydrolysis of glycosidic derivatives. ${ }^{15}$ Concentrations of quercetin obtained for wines from the Tangará region were similar to those reported by Gris et $a l .{ }^{5}$ who analyzed Merlot wines from São Joaquim, in Santa Catarina State.

The compounds flavan-3-ol (+)-catechin and (-)-epicatechin were identified and quantified in all samples analyzed. The use of ANOVA $(p<0.05)$, evaluating two factors, evidenced that the contents of (+)-catechin and (-)-epicatechin are influenced by the harvest and the region of culture. The highest (+)-catechin contents were observed in the Merlot wines from Tangará and Água Doce, while for (-)-epicatechin the samples produced in Água Doce had the highest levels. On the other hand, the highest (+)-catechin contents were observed for the 2012 and 2013 harvests, while the concentration of (-)-epicatechin was highest for the 2013 harvest. These two compounds are the major flavan-3-ols found in wines, being derived from the peel and seeds of the grapes. ${ }^{36}$ The concentrations of (+)-catechin and (-)-epicatechin obtained in this study are higher than those determined by Gris et al. ${ }^{3}$ in Merlot wines from the region of São Joaquim, in southern Brazil. The content of (-)-epicatechin obtained for wines from the Campos Novos region is similar to the values found by Cadahía et al. ${ }^{15}$ in Spanish Merlot wines.

The ANOVA results obtained considering the region and harvest showed that both factors significantly influenced the content of tyrosol in samples of Merlot wines. Tyrosol is produced by yeast during fermentation, with the precursor tyrosine. ${ }^{4}$ The content of this amino acid can be affected by the soil composition, vineyard management techniques and climate, which in theory could explain the differences observed in the wines from the different regions. Concerning the harvest, Gris et al. ${ }^{4}$ suggest that the high reactivity and susceptibility of phenolic compounds to reactions could explain the evolution of the content of tyrosol during the wine storage period, as observed for the wines of Água Doce and Tangará.

Low trans-resveratrol concentrations were found in this study, when compared to data reported by Gris et al. ${ }^{4}$ following a study on the stilbene content of Brazilian wines from the São Joaquim region and by Cadahía et al. ${ }^{15}$ for Merlot wines of the Denomination of Origin Navarra, Spain. The stilbenes profile is dependent on numerous factors, such as the vinification process, climatic conditions of the growing region and fungal infections in the vines. ${ }^{15}$ The content of trans-resveratrol was influenced by the region and harvest, according to data obtained when applying ANOVA $(p<0.05)$. Wines produced in Campos Novos from the 2012 harvest presented a higher concentration of trans-resveratrol. The differences between harvests and regions can be attributed to variations in the proportion of resveratrol in the free and glycosylated forms, since the glycosylated form can be broken down in hydrolytic reactions. ${ }^{37}$

The in vitro antioxidant activity of Merlot wines was evaluated based on their ability to capture the free radicals DPPH and ABTS. The results are shown in Figure 1, where a significant antioxidant activity of the wine samples can be observed, with values ranging from 8.03 to $15.29 \mathrm{mmol} \mathrm{L}^{-1}$ TEAC. The Merlot wines produced in the harvests of 2013 and 2014 were considered to be more efficient in capturing free radicals, except for the Tangará region. Regarding the region, the samples from Tangará and Campos Novos had higher values. Similar behavior was observed for the content of total polyphenols. The antioxidant activity of Merlot wines produced in new wine regions of Santa Catarina State was higher than the values found by Mulero et al. ${ }^{38}$ However, the results obtained in this study were lower than those observed by Gris et $a .^{3}{ }^{3}$ in red wines from São Joaquim, Planalto Catarinense. According to Frankel et al. ${ }^{39}$ the antioxidant activity is considered partially responsible for the beneficial effects of moderate wine consumption.

The correlation between the antioxidant activity and phenolic content of the wines was evaluated by simple correlation analysis. A statistically significant correlation $(p<0.05)$ between the total polyphenol concentration and the antioxidant activity determined by DPPH $(\mathrm{R}=0.66)$ and ABTS $(\mathrm{R}=0.67)$ was observed. On analyzing the phenolic compounds quantified in this study, there was a statistically significant positive correlation $(p<0.05)$ between the antioxidant activity measured by the capture of the ABTS radicals and the vanillic $(R=0.62)$ and syringic acids $(R=0.53)$. Vanillic acid has previously been cited as a phenolic compound with an important role in the capturing of free radicals in vitro by Ślusarczyk et al. ${ }^{40}$

\section{CONCLUSIONS}

This is an initial study about the phenolic composition, volatile profile and in vitro antioxidant activity of Merlot wines produced in three new wine-growing regions of Santa Catarina (Brazil) using spectrophotometry, GC-MS and HPLC-DAD methods. Differences 
between the wines produced with the same grape variety but from different geographic regions and harvests were evident, in terms of volatile compounds, phenolic compounds and antioxidant activity. Positive correlations were observed between the content of quantified phenolic compounds, especially syringic acid and vanillic acid, and the in vitro antioxidant activity observed in wines. High concentrations of hydroxycinnamic acids are characteristic of wines produced in the Tangará region, as well as high antioxidant activity in vitro. High concentrations of phenylethyl acetate, ethyl cinnamate and $\gamma$-nonalactone, which contribute to the aromas of red fruits, coconut, peach, roses and honey, were also observed in the wines of this region. For the Campos Novos region, high concentrations of trans-resveratrol, tyrosol, flavonols and hydroxycinnamic acids were observed, as well as the esters ethyl isovalerate, ethyl 2-methylbutanoate and ethyl hexanoate, which present the aroma attributes of sweet fruits, strawberries, apples and spices. On the other hand, for the Água Doce region, it was not possible to clearly define the main chemical constituents of the wines analyzed, evidencing the importance of conducting further studies on Merlot wines produced in this region. All of the samples analyzed presented a considerable content of fatty acids, which at high concentrations contribute unpleasant odors to the wines. In this regard, further studies should be carried out in order to understand why the synthesis of fatty acids is accentuated during the elaboration of wines from these three new wine-growing regions. In conclusion, environmental factors play an important role in the quality of the wines evaluated and influence the chemical composition in terms of volatile and non-volatile compounds.

\section{SUPPLEMENTARY MATERIAL}

Table 1S and Figure 1S are freely available at http://quimicanova. sbq. org.br, in PDF format.

\section{ACKNOWLEDGEMENTS}

The authors acknowledge EPAGRI - Experimental Station of Videira for providing instrumentation for this study, the Coordenação de Aperfeiçoamento de Pessoal de Nível Superior (CAPES) for providing Prodoutoral Scholarship (S. G. Arcari), and the Conselho Nacional de Desenvolvimento Científico e Tecnológico (CNPq) for financial support.

\section{REFERENCES}

1. Mira de Orduña, R.; Food Res. Int. 2010, 43, 1844.

2. Falcão, L. D.; de Revel, G.; Rosier, J. P.; Bordignon-Luiz, M. T.; Food Chem. 2008, 107, 497.

3. Gris, E. F.; Mattivi, F.; Ferreira, E. A.; Vrhovsek, U.; Pedrosa, R. C.; Bordignon-Luiz, M. T.; Food Chem. 2011, 126, 213.

4. Gris, E. F.; Mattivi, F.; Ferreira, E. A.; Vrhovsek, U.; Wilhelm Filho, D.; Pedrosa, R. C.; Bordignon-Luiz, M. T.; J. Agric. Food Chem. 2011, 59, 7954.

5. Gris, E. F.; Mattivi, F.; Ferreira, E. A.; Vrhovsek, U.; Wilhelm Filho, D.; Pedrosa, R. C.; Bordignon-Luiz, M. T.; J. Food Compos. Anal. 2013, 31, 31.

6. Protas, J. F. da S.; Camargo, U. A.; Vitivinicultura Brasileira, IBRAVIN/ EMBRAPA Uva e Vinho: Bento Gonçalves, 2010.

7. Jiang, B.; Xi, Z.; Luo, M.; Zhang, Z.-W.; Food Res. Int. 2013, 51, 482.

8. Noguerol-Pato, R.; González-Barreiro, C.; Cancho-Grande, B.; SimalGándara, J.; Food Chem. 2009, 117, 473.
9. Heras-Roger, J.; Díaz-Romero, C.; Darias-Martín, J.; Food Chem. 2016, 196, 1224.

10. Ivanova-Petropulos, V.; Hermosín-Gutiérrez, I.; Boros, B.; Stefova, M.; Stafilov, T.; Vojnoski, B.; Dörnyei, Á.; Kilár, F.; J. Food Compos. Anal. $\mathbf{2 0 1 5}, 41,1$.

11. Arcari, S. G.; Caliari, V.; Sganzerla, M.; Godoy, H. T.; Talanta 2017, $174,752$.

12. Singleton, V. L.; Rossi, J. A. J.; Am. J. Enol. Vinic. 1985, 16, 144.

13. Brand-Williams, W.; Cuvelier, M. E.; Berset, C.; Lebensm.-Wiss. Technol. 1995, 28, 25.

14. Re, R.; Pellegrini, N.; Proteggente, A.; Pannala, A.; Yang, M.; RiceEvans, C.; Free Radic. Biol. Med. 1999, 26, 1231.

15. Cadahía, E.; Fernández de Simón, B.; Sanz, M.; Poveda, P.; Colio, J.; Food Chem. 2009, 115, 639.

16. Thompson, M.; Ellison, S. L. R.; Wood, R.; Pure Appl. Chem. 2002, 74, 835.

17. Revi, M.; Badeka, A.; Kontakos, S.; Kontominas, M. G.; Food Chem. 2014, 152, 331 .

18. Chen, S.; Wang, D.; Xu, Y.; J. Agric. Food Chem. 2013, 61, 9712.

19. García-Carpintero, E. G.; Sánchez-Palomo, E.; Gallego, M. A. G.; González-Viñas, M. A.; Food Res. Int. 2011, 44, 1549.

20. Peng, C. T.; Wen, Y.; Tao, Y. S.; Lan, Y. Y.; J. Agric. Food Chem. 2013, $61,1542$.

21. Welke, J. E.; Zanus, M.; Lazzarotto, M.; Alcaraz Zini, C.; Food Res. Int. 2014, 59,85 .

22. Gambetta, J. M.; Bastian, S. E. P.; Cozzolino, D.; Jeffery, D. W.; J. Agric. Food Chem. 2014, 62, 6512.

23. Pereira, V.; Cacho, J.; Marques, J. C.; Food Chem. 2014, 162, 122.

24. Coelho, E.; Perestrelo, R.; Neng, N. R.; Câmara, J. S.; Coimbra, M. A.; Nogueira, J. M. F.; Rocha, S. M.; Anal. Chim. Acta 2008, 624, 79.

25. http://www.flavornet.org/flavornet.html, accessed November 2020.

26. Comuzzo, P.; Tat, L.; Tonizzo, A.; Battistutta, F.; Food Chem. 2006, 99, 217.

27. Escudero, A.; Campo, E.; Fariña, L.; Cacho, J.; Ferreira, V.; J. Agric. Food Chem. 2007, 55, 4501.

28. http://www.thegoodscentscompany.com, accessed November 2020.

29. Welke, J. E.; Manfroi, V.; Zanus, M.; Lazarotto, M.; Alcaraz Zini, C.; J. Chromatogr. A 2012, 1226, 124.

30. Valentin, L.; Barroso, L. P.; Barbosa, R. M.; de Paulo, G. A.; Castro, I. A.; Food Chem. 2020, 302, 125340.

31. Rocha, S. M.; Coelho, E.; Zrostlíková, J.; Delgadillo, I.; Coimbra, M. A.; J. Chromatogr. A 2007, 1161, 292.

32. Antalick, G.; Perello, M. C.; de Revel, G.; Am. J. Enol. Vitic. 2014, 65, 293.

33. Dourtoglou, V.; Antonopoulos, A.; Dourtoglou, T.; Lalas, S.; Food Chem. 2014, 159, 181.

34. Kotseridis, Y.; Baumes, R.; Skouroumounis, G. K.; J. Chromatogr. A 1998, 824, 71 .

35. Qian, M. C.; Fang, Y.; Shellie, K.; J. Agric. Food Chem. 2009, 57, 7459.

36. Chira, K.; Schmauch, G.; Saucier, C.; Fabre, S.; Teissedre, P. L.; J. Agric. Food Chem. 2009, 57, 545.

37. Mattivi, F.; Reniero, F.; Korhammer, S.; J. Agric. Food Chem. 1995, 43, 1820 .

38. Mulero, J.; Pardo, F.; Zafrilla, P.; J. Food Compos. Anal. 2010, 23, 569.

39. Frankel, E. N.; Waterhouse, A. L.; Teissedrespt, P. L.; J. Agric. Food Chem 1995, 43, 890 .

40. Ślusarczyk, S.; Hajnos, M.; Skalicka-Woźniak, K.; Matkowski, A.; Food Chem. 2009, 113, 134. 